\title{
sciendo
}

DOI: 10.2478/abcsj-2019-0002

American, British and Canadian Studies, Volume 32, June 2019

\section{Editor's Note: On Translation, Interpretation and the Commonwealth of Cultures}

Few cognitive skills have made a mark so indelible on intellectual and culture history, indeed on the evolution of human civilization as the act or art of translation. An in-built, immanent trait, defining of bumans alone - the only creatures capable of transferring meaning - translation is embedded in the various historical contexts of all ages. Elusive and intractable at times, the trace of translation is indelible in ways that have accompanied literacy 'since the dawn of time'. As an operation partaking of any act of reading, translation fulfills both a heroic and a hermeneutic role that is inextricably linked to the theory and methodology of interpretation. Inseparable, writing and translation find themselves in a biunivocal relationship, working synergistically toward the unfolding of meaning-making processes. Problematical, raising innumerable questions as to the status of translation and its unsettling relation with the original work, this ongoing dialogue taps into the vast reservoirs and areas of scholarship that translation practice invites, areas ranging from the anthropological, to the aesthetic, the ethical and the political.

Implicit in all fundamental modes of representation, translation has engendered some of the most contentious and variegated of critical responses. As both process and product, translation yields to polarities and oppositions of the most inveterate types. Deemed in some quarters as a secondary, periphrastic and parasitic activity feeding on a primary work, in others as a useful, yet for the larger part inconsequential tool, an inspiration, or, as the case may be, an enabling and emancipatory instrument of power, translation is yet to receive the recognition that it deserves.

Owing a great debt of gratitude to the tremendous encyclopedic breadth constitutive of the interdiscipline of translation studies, the present volume is intended less as a scholastic, and more as a metafictional, 'ineffable' exercise in cross-cultural appraisal; what we propose here in other words is to consider 
the 'story of translation' in the petites histoires that testify to its indispensability, versatility and enduring quality across the centuries. Exploring the trope and motif of the translator and interpreter in Anglophone literature, the volume casts a wide net, inviting mixed, imbricated reflections on translation as a quality intrinsic to buman nature and the structures of the human imagination.

In a revealing piece on translation as a metaphor of transformation and otherness, Randall Stevenson sheds new light on the translational aporias and the aesthetics of situatedness foregrounded in Joseph Conrad's writing. Tentative, subject to Conrad's innermost hesitations and distillations, the resort to translation, particularly in its literal form, lays bare the author's stylistic and semantic insecurities, the ultimately felt apprehensions in Conrad's renditions of the subject. More significantly, Stevenson shows, as well as pointing to the author's deeply felt tension between Englishness and foreignness in his own, first-hand experience, mistranslations and malapropisms are mechanisms of character portrayal and of conveying cultural difference. Conrad's recourse to translation forms an integral part of his endeavours to capture the metaphysics of his subject, central to which is the figure of the foreigner. In Conrad's fictions, translation thus becomes a site of alterity, symbolical of the constant deferral of meaning in the expression and re-expression of event and character. As dramatized in his 'imports' from Flaubert and the French masters, translation in Conrad's writing marries poetic license and the ethical stance, working toward the rendering visible of the voice of the Other. "One does what one can (on fait ce qu'on peut)': Joseph Conrad as Translator" contributes a highly insightful understanding of the subtlety and obliquity of Conradian poetics and the role of translation as mediation between the tale and its teller. A particularly rewarding part of this contribution is that it redeems some of the least researched faculties of the author, the irony and the humour.

Starting from the Borgesian metaphor of the black swan, Bran Nicol explores translational and intercultural exchange in Ted Chiang's "Story of Your Life" (1998) and Denis Villeneuve's Arrival (2016), dystopian projections of posthuman times. Conducting a close reading of the text/ film, Nicol deconstructs the 'black swan fallacy' within the paradigm of 
translation as empowerment. In the fictions above, a specialist in contrastive linguistics, assisted by a scientist, is called upon to moderate in the encounter between aliens and humans, in so doing examining the relations and correspondences between language systems. The novel envisions creative forms of non-sequential, performative languages. The heptapods's language is thus a semasiographic language akin to that of the Tralfamadorians in Kurt Vonnegut's Slaughterhouse 5. Like Vonnegut's aliens, the heptapods are endowed with the faculty of prescience, being able to 'remember the future', which renders crucial significance to the human-alien encounter. Unlike glottographic or constructed languages, semasiographic languages combine pictographs and concepts to produce encrypted messages that call for multiple layers of decoding and high-level analyses conducted with forensic exactitude. As a manifestation of this form of highest expertise in language, translation proves a rare asset in conceptualizing difference. Touching upon abstruse aspects of the metalanguage of translation, Nicol rethinks the epistemological and ontological structures underpinning language practice as apparent in Arrival, the cinematic adaptation of "Story of Your Life," which he dubs a 'bu-fi' genre. Against the current backdrop of a horizon of expectation featuring humans as the endangered species - increasingly dominant in the global imaginary - the investigation could hardly be timelier.

Translation as an unparalleled testimonial for the reshaping of identity forms the object of Mihaela Mudure's enquiry in "Oksana Marafioti: Translating Identities." Here Mudure profiles the RomaAmerican author Oksana Marafioti with reference to the predicament of the immigrant subject in the volatile, disquieting context of the global world. Approaching a diversity of interrelated themes such as mobility, movement, miscegenation, Mudure tackles the numerous cultural valences of translation and its bearing on identity, belongingness, and cultural resistance in an increasingly borderless world. Crisp in tone, touching upon the very substance of lifewriting, the profoundly moving significance of mémoires, and the inevitable struggle of transcoding, this graceful, empathetic account of Marafioti's work is an invaluable appraisal of the public and the hidden faces of the translation experience. 
Delving deep into the misconceptions and ambivalences surrounding the shadowy, murky waters of the translator's/ interpreter's job, Alina Pelea accompanies the fictitious Hajji Baba, of Ispahan to England on an adventurous journey illustrative of the meanders and tribulations of the world's 'second oldest profession', in an attempt to revisit old clichés and stereotypes associated with it. Authored by James Justinian Morier, British writer and diplomat, the novels in the Hajii Baba series, of which Pelea analyses The Adventures of Hajji Baba, of Ispahan, a tortuous journey that entails delightful detours of interpretation and diplomacy in England, speak volumes about the incongruities and inconsistencies, of the job. A creative genius, credited with introducing new words in the English language, Morier is best known for his novels about the Qajar dynasty and the Hajii Baba series, the latter having inspired a humanitarian mission.

Anca Ignat and Alexandru M. Călin embark upon the assiduous quest of observing renditions into Romanian vernacular of the pronominal forms 'you' and 'thou', in Shakespeare's Romeo and Juliet. The scope of the study is that of revalorising the associative meanings in the Shakesperean use of the pronouns, the social and affective implications of the two. The pursuit stems from the authors' disaffection with twentieth century translations into Romanian of the play, translations that obliterate the distinct, modulated use of the two pronouns in the Shakespearean work. Part of an ambitious, comprehensive project "Shakespeare for the Third Millennium," the paper focuses on the 'shared sonnet' in Romeo and Juliet, of Act 1, Scene 5, offering an opportune rethinking of the Shakesperean sonnet as an idealized form of love.

At the heart of postcolonial studies, translation as a mode of partial requital, of compensating for the experience of colonialism finds perhaps its most congenial expression in the discourse of the Anglo-Indian author Salman Rushdie, doubtless, one of the most iconic figures in the scene of postcolonial/ postmodern writing, among the world's most widely translated authors, and an experienced translator in his own right. Subversive and chameleonic, a 'guru' of bybridity and double visions, Rushdie, is well versed in celebrating difference, his work being profuse in images of translators up against the danger of the appropriation and domestification of the 
postcolonial original. Looking at the potential for the moral retribution of translation as a reiterative theme in Rushdie, Dana Crăciun's "A Portrait of the Writer as a Translator: Salman Rushdie and the Challenges of Postcolonial Translation" considers instances of translation and self-translation in Rushdie's work within the prolific postcolonial vantage point of majorityminority languages/ cultures. Emblematical and integrative in scope, taking stock of the latest developments in global studies, Crăciun's approach posits that intralingual and interlingual translation are inevitably, inexorably forms of postocoloniality, a condition Rushdie embodies with a great degree of exemplarity, ironically, and canonicity. A textualist approach in the 'conventional' style, the paper is informed by a revolutionary concept marketed by another seminal figure of postcolonial studies, Homi Bhabha, that of the Third Space of cultural liminality, the very locus of translation.

Aiming to bring new perspectives to the prodigious realm of translation theory and practice, the present collection is an excursus in the margins of an otherwise encyclopedic, highly established domain, glimpsing in the backstage of the experience. It is as well meant as a tribute to the remarkable talent of translators and interpreters out there, their wit, selflessness and humilitude, above all their commitment to cross borders, fill gaps and get the message across; to echo the Rushdie of Imaginary Homelands, to an article of faith: that "something can also be gained in translation," the commonwealth of cultures.

ADRIANA NEAGU, Babes-Bolyai University, Cluj-Napoca, Romania

\section{Works Cited}

Bhabha, Homi K. The Location of Culture. Abingdon: Routledge, 1994.

Rushdie, Salman. Imaginary Homelands: Essays and Criticism 19811991. New York: Viking, 1991. 